\title{
Introducing some secular and feminist theological insights of body into theological conversation
}

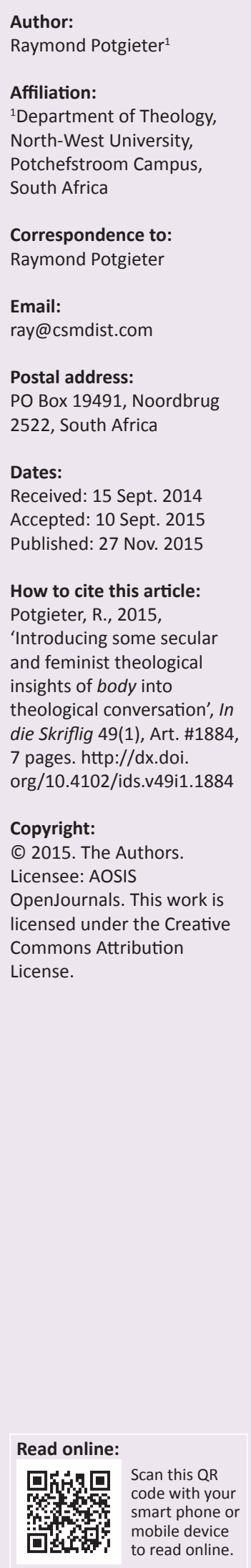

Whether the conversation is casual or professional, words such as body, woman, and heart are part and parcel of community conversation. However, the understanding of the meaning of a specific word such as body may prove to be elusive, vague or alternately take on a complexity often removed from ordinary conversation. Although the insights from Christian feminists have enriched the traditional theological understanding of the word body their insights are not always associated with the general use of the term. A richer understanding of the word results in recapturing the meaning of body, not only for women but also for society's theological conversation and 'body-talk' as a whole.

Ongeag of die gesprek informeel of professioneel is, bly die woorde liggaam, vrou en hart deel van die gemeenskapsgesprek. Die begrip of betekenis van ' $n$ bepaalde woord soos liggaam, kan ontwykend vaag of alternatiewelik 'n kompleksiteit aanneem wat van gewone gesprekvoering verwyderd is. Feministe het onder andere ook van sekere woorde, waaronder besitreg geneem en dit aan kritiese teologiese ondersoek onderwerp. Hulle insig verryk die tradisionele begrip van die woord - nie net vir vroue nie, maar vir teologiese diskoers in die geheel.

\section{Introduction}

In his taxonomy Jared Diamond (1991) classifies humans as the taxon pongidae of a 'third chimpanzee'. ${ }^{1}$ He does so because of the uniqueness of human societal behaviour. Rousseau ${ }^{2}$ (n.d.:20ff.) lamented the secular fall of humankind from a natural state to that of civilised society, thus developing the Renaissance rebirth concept ${ }^{3}$ which included both male and female. By the 19th century the sexualised female body was evident in cultural understanding, and for instance identified the prostitute as a danger to society. In 20th century commercialism the psycho-sexual economy came about with the focus on that what differentiates women from men. Continuation of the debate about these differences and women's experiences, seek to delineate 'the true essence of Woman' (Gallagher \& Laqueur 1987:xv).

Debate in a postmodern setting, however, has made truth a subjective term. There is no one truth that may be claimed to be right. In other words, to claim one behavioural truth as interpretative of the whole of society is disputed. Rather a variety of claims of equal credibility are to be considered. For that reason reformed theologians ought to be aware of the nuances that accompany the word body in both sacred and secular contexts, not least as interpreted by Christian feminist theologians. These theologians have added insightful dimensions to the concept of body to meaningfully engage in present-day theological conversation. For that reason this article seeks to view the generic use of body in societal conversation with some focus on feminist theology.

In the light of the aforementioned, Christians need to seriously consider that the Bible does not speak about everything, but rather speaks about everything it intends to teach the church. ${ }^{4}$ To that end many sincere individuals' minds are clouded by the myriad of views regarding concepts

\footnotetext{
1.Taxonomically human relatives are said to be the common chimpanzee and in particular the bonobo chimpanzee of the Democratic Republic of the Congo. See also the 'chain of being' as explored by Schiebinger (1999:21-31) from the feminist perspective.

2.Rousseau (n.d.:21ff.) had some set notions about women in society reflecting Enlightement sentiments. This is not explored in this article.

3.The Renaissance Greek ideal was taken from Aristotle's ethics and kalokagathia [blended virtue and aesthetics] and was developed by humanists into the understanding of inclusive socialising and education (Groppe 2006:550-551).

4.This statement ought to be understood in a world facing the complexity of secularism, secular science and the phenomenon of religious extremism and their accompanying philosophies and worldviews. These hold major sway for any interpretation of society and therefore impacts any understanding of a genetic concept such as body. Reformed theology affirms that true religion is based on revelation and not on human interpretation in the context of experience.
} 
common to both the Bible and secular vocabularies. The words ${ }^{5}$ body, mind, heart and soul immediately spring to mind. For that reason when Christians employ a term such as body they need to take the contemporary use of the word into consideration. They need a robust grasp of the word body if they are to engage those inside as well as outside of the church in a meaningful manner.

For that reason this article will firstly give an overview of the generic societal use of the word, and secondly, a generic overview of the feminist theological use of the word body. Whilst this article will not be comprehensive, it will attempt to bring to the fore some of the more recent meanings ascribed to the word body. It will also strive to indicate that Christians need to take serious cognisance of the understanding of the complexity of terminology such as body not only in society but also in modern theology.

\section{A sample of the generic use of body reveals the societal complexity involved}

Some indication of the complexity associated with the word $b o d y^{6}$ is necessary because a third millennium discussion of the body is also defined by concepts such as the gendered body, Freudian body, Foucaultian body, ${ }^{7}$ body builder, disabled body, conscious or unconscious body, healthy body, sexual body, super body, sick or impaired body, neural body, spiritual body, and so on.

\section{A sample of popular uses of body in the wider community}

Body hyperbola 8 is associated with many science fiction genre characters such as Superman, Spiderman, Mr Incredible and more recently the female Thor. ${ }^{9}$ Associated with body are fictional scenarios which challenge the imagination. For instance it includes dematerialisation of the body, transmission of the body over distance, morphing from one form of body into another. Similarly there is the further portrayal of superhuman efforts and feats as the norm found in popular fiction such as Ian Fleming's James Bond, Wilbur Smith's heroes and the Hollywood champions. ${ }^{10}$

5.De Botton (2013:13) makes the observation that once you shake off the hold of a specific faith, religions (Christianity included) may be regarded as 'repositories of a myriad concepts'. Body is simply one of them. Bruce (1982:130)cautions 'Few would care to distinghuish sharply among the four elements "heart" (kardia) "soul" (psuche), "mind" (dianoia) and "strength" (ischus)" (cf. also Dt 6:5; Mk 12:30.)

6.I omit concepts such as a body of data, information, proof, lies, evidence, light and so forth. It is interesting to note too that in 'new definitions of feminist theology' Kassian (2005:113ff.) does not include the concept of body. This may have been an omission but several attempts to contact the author failed and so this cannot be omission but

7.Among others Foucault deals with the body as an object of knowledge, the target of power and as a way of expressing the self ethically (cf. Protevi 2013:51-57).

8.The consequence of techno-culture, science fiction, gender theory as explored by Mitchell (2006).

9.This is not a remodeled Thor into a feminine She-Thorilda or a Lady-Thor but an uncompromising Thor displaying a female body needed for a physical hero (in) to (BBC News 2014). For a glimpse into the world of superheros a simple internet search will instantly reveal a bewildering company of these imaginary characters.

10.These are far removed from Charlemagne's twelve paladins, or for instance the Song of Roland (Crosland 1999), or the emphasis on saints and missionaries, o Arthur's Knights of the Round Table. Most of these 'heroes' were usually associated
To add to the fiction genre, communal conversation must also contend with society's advertising dynamic. Advertising agencies marginalise the fuller appreciation of all that goes into the complexity associated with the meaning of body. One example is the idealised female or male body utilised in the promotion of commercial products (Jhally 1990).

\section{A sample of associating body: Spiritual and metaphorical}

What is often associated with the fictional 'super' feats of the body is that it is invariably related to some form of spiritual empowerment. ${ }^{11}$ This translates into secular mysticism with associative mystical terms. Think of popular children's films ${ }^{12}$ where such relationships as 'out of body experiences', demonic possession of the body or empowerment of a body attribute such as the intentional gaze of a character to induce flames. Manifestation into multiple bodies all similar to the original character, is another favourite excursion of creative imaginations.

Another way of employing body in a traditional sense may be found in its use as a metaphor in architecture for example when discussing a building. On the other hand the associative gender of 'she' is, for instance linked to a ship. The concept of body is clearly very complex to define in its societal use and even more so when it is also linked to gender.

\section{Samples of wide ranging body gender sexuality}

In addition to the aforementioned spiritual element is the use of body in signage symbols and symbolic language (Meir et al. 2007). On the one end of the spectrum the female and male body features prominently in cinema, whilst on the other end it is also revealed as emasculated, a-sexual and impotent forms of feminity and masculinity (Fouz-Hernández 2009). The list could be furthermore extended to include scientific racism and sexism with regard to the female body (Spelman 1999:23).

The term body took on visible significance when the media screened bodies - mangled, in body bags and scattered body parts - during the aftermath of the 9/11 attack. Betcher (2013:26ff.) is of the opinion that these terrible scenes in turn also brought the spotlight to bear upon those individuals with damaged, infirm, disabled or diseased bodies, many of whom are often confined to homes and institutions for care and medical reasons. For Betcher (2013) the range of challenges associated with the body must be regarded as part and parcel of an inclusive urban challenge to include the whole of society.

\section{Samples of integrated 'body-talk'}

There are also the claims of a symbiotic relationship between the physical and spiritual as they merge in the body during

with some or other Christian attribute contributing to some particular quest of valour. I do not qualify the use of 'heroes'.

11.An Internet search quickly identified the sources of power for Green Lantern in his power ring, the X-Men in mutation, Iron First finds his in Chi and so on

12.See the academic syllabus of the Hogwarts School of Witchcraft and Wizardry throughout the Harry Potter series. 
yoga. Some claim the same experience for body art (Schildkrout 2004). Furthermore the human body, as a psychosomatic whole, allows for perceptions (Wilke 2007:147) of the animate and inanimate, dreams, ecstasy, physical sensations, selfreflection and death as opposed to sickness. These give rise to the richness of body as a concept when associated with concepts such as mind and spirit..$^{13}$

In this regard Wieseltier (2005:437) explores the Jewish metanarrative of the body, to conclude that 'The mind has become the brain'. In other words, the metanarrative categorises and structures the thought process and conversation of the person or group. Another opinion is held to by Baruch (1999) who regards the physical problem of endiometriosis ${ }^{14}$ as so debilitating to the sufferer that she describes it as 'endiometriosis: bleeding body and soul' ${ }^{15}$ It not only affects the physical body but the very psyche as well. The complexity involved to understand the body holistically is not a new concept (Bentley 1933:578). Outside of physical science, organic woman and man tend to be viewed as more complex than is usually accepted when a pure somatic perspective is adopted.

Contemporary archeology increasingly adopts interpretations from a semiotic perspective. Archeologists now view bodies found in excavations as humans who once occupied bodies. Viewing and understanding them as such, within an ancient context, allows for a more comprehensive approach (Joyce 2005). Richer insights emerge from this approach, adding to an integrative, social understanding of being a person within a community ${ }^{16}$ and a material culture. In other words the body is not just seen as a static artifact, but is also reflective of a need for its social understanding (2005:140).

A final example will be that of generic personal identity. German neo-humanism developed the concept of the body (male and female) as gestalt, unifying beauty and goodness in a social construct with education (Groppe 2006:555-556). By the 20th century the drive was not to return to nature anymore, but to a new naturalness through the influence of dance, photography and youth movements (Groppe 2006:558). Personal image was in the making through a fusion of body culture (male and female) with its own distinctive norms and values (2006:559). These views questioned theological corporeality. Dichotomies began to be questioned and fell by the wayside since dichotomies such as mind, soul and body are not universal (Brougham \& Mitchell 2003:245). The self cannot be reduced to a physical concept of body alone, nor can it find some relation to an external point of reference for fuller identity. Material corporeality allows for the freedom

13.Wilke (2007:147) explores the subservience of wholeness to pagan religious dualisms and as an entelechy from within the psychophysical.

14.This is a disease that affects women and is the result of endometrial tissue forming in places other than the lining of the uterus (Baruch 1999:92). While Baruch does not particularly try to understand the body apart from some pertinent physiological observations, I merely use this article to illustrate the need for authors to expand their vocabulary when speaking of the body.

15.She seems to substitute the word 'pscyhe' for soul early on in her article.

16.Characteristics of modern society are the sense of loss of community and feeling of alienation (De Botton 2013:23, 25). to claim: 'I am my body' and 'I have a body' (Ringleben 2007:145; cursive in the original) reflecting the inclusiveness of all that goes with living or being alive.

\section{A sample of postmodern perceptions of the body}

Foucault explored the traditional and modern medical implications for understanding the history of societal meanings ascribed to the term body. He traced the development of its meaning as a move towards a bio-organic perception $^{17}$ (Schiebinger 1999:21-31). Foucault reveals that the Reformers' preoccupation with the body took place within the context of a social contract. ${ }^{18}$ Consequentially in upholding this power structure are the reformed emphasis on judicial issues, punishment, life and domination (1999:53-54). Finally he also dealt with body in terms of an ethical concern. Diet, sex, exercise and sleep are to be seen as activities of the self (1999:54-55) within the context of society. Body cannot be seen outside of society and power structures.

Adding to the complexity surrounding body is the problem of determining the meaning of words and texts. Roland Barthes (1915-1980) showed how the nuances and varieties of the meanings of words and texts in society render the intended meaning of the original writer impossible. Words do not have ultimate meaning. Writing destroys identity evident in a western masculine interpretative bias and becomes a cause for feminist contentions (Allen 2003:74ff.). By implication this would reflect on the intricacy in settling upon the meaning of the word body. For Eco (1990:60ff.) the emphasis on meaning is not necessarily on words, but on narrative. For that reason the word body would find its interconnectedness with life as metatext. ${ }^{19}$ In this sense the interest is not about the story of life but about the commentary the metatext elicits about life and real living (Farronato 2003:73). The implication for the concept of body is obvious.

Claiming full understanding of the word body in third millennium societal or theological conversation would be presumptious.

Feminist theologians have developed the concept of body in theological constructs. An excursion into some of the scholarly insights from religious feminism and feminist theologians will reveal this fluidity of meaning to be unlike that of traditional reformed theology. This challenge must be seen by the reformed church in the sense of Ecclesia reformata semper reformanda ${ }^{20}$ [the reformed church is always

17.See for instance the taxonomy in Feminist theory and the body (Balsamo 1999:278-280). The content of the book covers categories such as woman as body, sexy bodies, bodies in science and biomedicine, after the binary, altered bodies, bodyspacematter, performing the body, et cetera.

18.In fact Protevi (2014:54-55) saw the human body as the target of power structured systems and the marks of this power (torture, ceremonies, forced tasks, etc.) on bodies testify to that.

19.Eco $(1990: 73)$ is careful not to lapse into overinterpretation and sets limits to interpretation. Nevertheless his own popular novels prove the interconnectedness of life and history (Coletti 2009:71ff.).

20.A variation of the common Ecclesia semper reformanda est [the church is always to be reformed]. 
to be reformed]. In this writer's view, it is necessary to meet the present-day challenge of a changing society and its vocabulary which continues to impact the church and its theological use of the word body.

\section{Feminist theology and body}

Feminism $^{21}$ is a contemporary emancipatory theology $y^{22}$ and philosophy that is variously shaped within society. Only some of the main tenets will be referred to as these in particular pertain to the concept body. Because of the wide range of the subject this article will focus on how the concept of body is influenced by a feminist take on social constructs and secondly, with the body as a concept being developed by feminist theologians into a theological construct.

\section{The social construct and body}

African women's theologies identify with feminist theology within the ambit of liberation. The focus is on a construction of theologies rather than a single theology taking into account the diversity of Africa regarding culture, race, religion and issues such as AIDS and bride-price (Phiri 2004:16ff.; cf. Moyo 2004). Though African women theologians do not overtly address body as theological concept it nevertheless implies the contexts of personal and communal living in Africa (Phiri, Haddad \& Masenya 2003). This social context is a far cry from body simply seen as a compilation of body parts and chemistry (Gibson 1981:288-289) extending far beyond the traditional 'küche, kirche, kinder' perception (Kassian 2005:24).

Within the social context feminism also formulates its own social questions and proposes answers to body centred gender that challenge historic and present cultural or traditional masculine driven theologians to re-evaluate their patristic and gender positions, not least to challenge a condescending approach to women. From the feminist perspective this is often done through raising the consciousness of the collective experience of women, ${ }^{23}$ not only in the west, but worldwide. Women all over share in some degree of discovery of solidarity in their conversations about a body consciousness in a gender shaped history. In Africa in particular, it developed alongside the movements towards liberation and injustice (Phiri 2004:21).

Rivera $^{24}$ (2010:119) argues that when body is degraded to flesh it has implications implying the subordination of

21.Feminist scholarship uses anthologies to explore the changing and growing voice of feminism' (O'Grady, Gilroy \& Gray 1998:13). This expresses the complexity of the subject in that it allows for divergence of opinion under the single theme of feminism per se.

22.Kassian (2005:9) identifies three stages of development in feminism, viz. naming of the self (1960-1970); naming the world (1970-1980); naming God (1980-1990).

23.For instance in raising consciousness the principle of speaking bitterness adopted by some feminists from Mao Zedong's political technique for cultural and political awareness. Bitterness gives way to anger (Kassian 2005:73ff.).

24.Mayra Rivera would be representative of the second generation feminist wave following in the footsteps of her sisters of the first as daughters of the Enlightenment (Braidotti 2011:185). Braidotti also makes the incisive point that the feminist belief-system was not theistic but civic. McDougall (2009) more the feminically identifies three waves of the sense of the direction into which feminist specifically identifies three waves of the sense of the direction into which feminist
thought and theology have developed. These waves successively address women in preaching and teaching offices (1840s - 1920s); addressing patriarchy and women to patriarchal structured realities. ${ }^{25}$ Kassian (2005:88) explores the implications of social complementarity ${ }^{26}$ from an ecclesial point of view. This exploration of necessity deals with hierarchy and primacy as divinely devolved authority (Kassian 1990:19, 31) and consequently with implications of submission to complete the binary with authority. Implicit in such a view of authority and submission, is the traditional Christian framework for understanding the implications for women and body.

Christian feminists challenged traditional social constructs by exploring binaries such as authority and subordination in a new way. That is, the concept of body must also be socially tested in the light of community and not simply accept patristic top-down interpretations. From a feminist theological position a new perspective emerged. Rivera (2010:123) attempts to put body in a wider though inclusive social context, ${ }^{27}$ in which body should not just be seen as an 'organized, aestheticized and objectified unit to which we (read women) are compelled to conform'. Rather it can be seen as a concept with a complex present located in a sociohistorical construct. This significantly moves away from defining woman on the basis of her body ${ }^{28}$ alone.

When the concept of body is marginalised it allows for some deviant social directions. One extremity of this is that it leads to the myth of racial or cultural purity (Rivera 2010:121). More to the point and purpose of this article is the idea of body isolation. Betcher seems to get her views from the concept social flesh (Beasley \& Bacchi 2007; Betcher 2010:2; 2013; cf. Rivera 2007). She uses it in a social contextual sense of an 'irreducible vulnerability' (Betcher 2010:119). Flesh becomes a focus on visibility as most women find living in cities experiencing the dynamism of daily living. Women recover the concept of body as they juxtapose 'alternative forms of beauty to those advancing the aesthetics of capitalism' (Betcher 2013:6) to those which would normally isolate them. New social urban values are identified and because of this social dynamic, theology is challenged to keep up with the urban woman. She speaks of theology becoming uncloistered in the city in its move away from the dogma of the traditional patristic enclosures (2013:13). This spin-off may also be seen in the impact it is having amongst Muslim communities moving toward women's self-determination. Women are beginning to challenge enforced cloistered religious identity ${ }^{29}$ through claiming it to be Islam-phobic in character (Braidotti

sexism (1960s - 1980s); and gender debates incorporating women world-wide (McDougall 2009:671).

25.The same argument of stricture could be mooted for a biotic approach to the generic body of all living organisms.

26.This would also be the views of both Piper and Grudem (2006).

27. Rivera primarily explores the Latina approach to body-talk. But this is relevant to South Africa as well with its increased cosmopolitisation and past history. She also relies to a great extent on apophatic (negative) anthropology to root her views so relies to a great extent on apophatic (negative) anthropology to root her views so as to allow a certain 'openness' to her views (Betcher 2010:115; cf. Padilla-Tallman 2006). See also Rivera's, The touch of transcendence: A postcolonial theology of
God (2007).

28.See Elizabeth Gould Davis' interpretation of history and the female biological or genetic makeup (Kassian 2005:119ff.).

29.Islamic feminism is for instance taught by Basharat Tayyab (1998). 
2008:4). This is not only a European phenomenon but is also found in Africa.

Subjecting body to social construct is a socially, not a theologically motivated move. In this sense it is impoverished due to the lack of robust theological instruments to address the situation. But, as has been made clear from the above, feminist theologians do not only attempt to widen the perspective that should accompany the concept of body, but also enrich contemporary theology in the process. For instance sexual violation of a woman's body has complex ramifications, not least having to live with the reality of violation. Traditional biblical instruments would allow for the understanding of the issue and address the matter of sin. A broader social awareness widens the context so that attention is also paid to for instance resisting any collusion which leads to unjust or prejudiced gender relations (McDougall 2009:677). An address of sin must be restorative by nature, lead to a recovery of self-esteem 'and lending them courage to resist gender oppression' (2009:678). But the same dynamic must also permeate the whole of society. This leads to more particular theological insights gained from Christian feminists.

\section{Body theology and dualisms ${ }^{30}$ in feminine theology}

A theology of persons ought to speak of the inseparable spiritflesh $^{31}$ 'where the hyphen marks a boundary of distinction that does not tend to separation' (Rivera 2010:122). Body cannot be divorced from a person but is necessary to form an intrinsic understanding of being human and of human existence (Ringleben 2007:145). This has some ramifications, as will be discussed.

With the corporeal intact, Rivera (2007) develops her theology of God, who may be absent to human grasp but present in the sense of touch. Implicit is the old binary problem of principal connection, viz. that of objectifying and subjectifying ${ }^{32}$ God. The question then occurs of how human beings stand in relation to God? If the problem is approached from divine absence (transcendence implying distance), a dualism is induced. Patristic influences developed this dualism into a father concept ${ }^{33}$ of divinity, which by implication suggests

30.Foucault's approach to dualisms neglected female sexuality (Brougham \& Mitcheil 2003:245).

31.An example of another inseparable would be that of McFague's $(1987: 68,72)$ exploring the metaphor of 'the world as God's body'. With that she explores ecotheology from a feminist perspective adopting panentheism (Potgieter 2013).

32.Objectification is a term key to feminist theology suggesting the depersonalising of the individual to, for instance an object of desire. This reduction ignores the greate narrative that accompanies a human being as being complex. Subjectification would be seen in the sense of imposing strictured limits upon women such as chastity, weak, emotional, and so on. The release from subjectification would be a move toward subjectivisation. This is reminiscent of the Foucaultian powe construct of the individual assuming an own identity and not one forced upon the person. A biblical safeguard in this respect would be to recognise any pretention to false innocence with respect to, for instance a claimed plight of oppression from advocating a patriarchal view (McDougall 2009:679). A term oppresson from adion direction in praxis.

33.Some scholars are of the opinion that because God is now perceived to be of patriarchal origin (masculine) and not of nature (creator), each generation must therefore rediscover and define deity for themselves in a new rational and imaginative way satisfying the development of its culture. gender differences where God is concerned and which by its very nature privileges men. Women are associated with immanence and the implication of seeking release into transcendence. Daggers (2010:197ff.) deals with this collapse of transcendence into immanence, suggesting that men are associated with transcendence that implies a process of movement away from the limitations of materiality to conclude with objectifying God (Daggers 2010:207). This is a view which Rivera seeks to address when she embarks on a search for the right relationship between female flesh and body in relationship to the divine (Rivera 2007:6, 91, 94-95). Traditionally this would compel a masculine interpretation, ${ }^{34}$ but the point is: transcendent or immanent, whatever the experience, the same ontological God is the God for men and for women $(2007: 88,126)$. God is the God of reality present in human life and experience.

This gendered and body shared relationship originates in the womb. Both genders come from and can never return to that first dwelling place, regardless of symbolic recreations or types offered as substitutes (Irigary 1993:33). But to theologise from the body or womb is risky (Isherwood 2010:128). To that end Rivera (2010:122-123) suggests an interesting approach - flesh must also be seen as the place where the Spirit materialises ('incarnates'; cf. 2010:122). The same idea was developed by Isherwood and Stuart (1998:11) when Mary's body became divinely associated as 'both site and recipient of revelation' and a fuller understanding of theology became possible. A new identity thus becomes possible. This challenged the patriarchal prejudices and traditional religion's structured God-concept, pertaining to the incarnation $(2010: 21,22)$. A new perspective on revelation was introduced. The female body, from the feminist point of view, becomes normative. It may be seen as the place in which 'the Word became flesh'. ${ }^{35}$ When developed in Whiteheadian ${ }^{36}$ style, it is a 'becoming', through process. ${ }^{37}$ Isherwood and Stuart (1998:34-35) suggest a Christian process of unfolding love in the complementary actions of both God and people, so much so, that theological absolutes are discarded and the consequential fluidity of values allow for creative development of body theology. 'The body is both the site and recipient of revelation'. From that moment when Mary accepted the Angel's message her body became the female normative for a fuller understanding of theology $y^{38}$ (Althaus-Reid \& Isherwood 2008:11). In other words it is a theology that expresses humanness through flesh. There is 34.This seems to be a continuation of the same argument put forward by Ruether (1983:229-230).

35.Cf. Baxter (2008:48) in which she develops the 'I am' experience theologically in the presence of the human experience of pain within the Christian community.

36.A.N. Whitehead (1861-1947) defined a process philosophy which developed into process theology (panentheism; cf. Potgieter 2013). Isherwood's ideas are also found in Ruether (2000:50) for whom God's immanence allows for an openness to God and for God to enter a process of becoming, the basis of an ecofeminist theology of liberation.

37.Althaus-Reid and Isherwood $(2008: 35,38)$ develop the ideas of the 'unfolding process of love' and contrast the receiving of wisdom at the expense of receiving God in the process.

38.The authors admit that this is only partially normative as each person experiences their body in their own special way (Althaus-Reid \& Isherwood 2008:9). 
more to the body experience and the domination of cultural interpretations; it is normative for theology $(2008: 2,3,22)$.

\section{Some tentative conclusions}

Whilst limited in its scope, ${ }^{39}$ this article should serve to show that in dealing with a subject such as body, it is not a matter of eavesdropping on secular or even feminist conversations. Nor is it only about denigration of the body, but also about the abstraction of its daily use. What is clear too is that body terminology in secular society is far removed from the once gendered theory and contained terminology. This has clear implications for the Christian community. Where body is concerned in the secular society, it is not merely a question of whether the developments are Christian or even committed to a feminist framework or not. One simply lives in a society which uses and abuses body in a myriad of ways. Pastors need to be aware of the fluidity of terminology, not least that of body.

When it comes to feminist theology the church ought to be deeply appreciative of the contemporary challenges to its theology. A greater awareness of the importance of feminist theology in societal context is welcomed for the theological appreciation of the concept of body. For instance congregations are made up of women and men who love and serve the Lord their God whilst experiencing the impact of gender and gender fluidity on a daily basis. It remains to be seen, however, if the development of body into a theological construct by feminist theologians will stand the test of time. Kassian's (2005:117) observation remains: 'Will feminist theological answers to questions allow for the furtherance of truth, without deviating from biblical truth?'.

\section{Acknowledgements Competing interests}

The author declares that he has no financial or personal relationships which may have inappropriately influenced him in writing this article.

\section{References}

Allen, G., 2003, Roland Barthes, Routledge, Abingdon.

Althaus-Reid, M.M. \& Isherwood, L., 2008, Controversies in body theology controversies in contextual theology, SCM, London.

Balsamo, A., 1999, 'Forms of technological embodiment: Reading the body in contemporary culture', in J. Price \& M. Shildrick (eds.), Feminist theory and the body: A reader, pp. 278-289, Taylor \& Francis, Abingdon.

Baruch, K., 1999, 'Healthwatch - Endiometriosis: Bleeding body and soul; empowering women for gender equity', Education and Transformation 41, 92-95, viewed 7 July 2014, from http://www.jstor.org/stable/4066204

Baxter, C., 2008, 'Cutting edge: Witnessing rites of passage in a therapeutic community', in M.M. Althaus-Reid \& L. Ishwerwood (eds.), Controversies in body theology, controversies in contextual theology, pp. 48-69, SCM, London.

BBC News, 2014, 'Marvel comics recasts superhero Thor - as a woman', viewed 15 July 2014, from http://www.bbc.com/news/entertainment-arts-28321806

Beasley, C. \& Bacchi, C., 2007, 'Envisaging a new politics for an ethical future, beyond trust, care and generosity - Towards an ethic of "social flesh"', Feminist Theory 8(3), 279-298. http://dx.doi.org/10.1177/1464700107082366

Bentley, M., 1933, 'Mind, body, and soul in medical psychology', The American Journal of Psychology 45(4), 577-591, viewed 7 July 2014, from http://www.jstor.org/ stable/1416190

39.1 have not, for instance explored Braidotti's (2011) more subjective approach incorporating the principle of movement in defining identity with ramification for feminism and body.
Betcher, S.V., 2010, 'Becoming flesh of my flesh: Feminist and disability theologies on the edge of posthumanist discourse', Journal of Feminist Studies in Religion on the edge of posthumanist discourse', Journal of Feminist Studies in Religion
$26(2), 107-118$, viewed 3 July 2014, from http://www.jstor.org/stable/10.2979/ 26(2), 107-118, view

Betcher, S.V., 2013, Spirit and obligation of social flesh: A secular theology for the global city, Fordham University Press, New York.

Braidotti, R., 2008, 'In spite of the times, the postsecular turn in feminism', Theory, Culture \& Society 25(6), 1-24. http://dx.doi.org/10.1177/0263276408095542

Braidotti, R., 2011, Nomadic theory: The portable Rosi Braidotti, Columbia University Press, New York.

Brougham, T.R.S. \& Mitchell, S., 2003, 'Body', in S. Hornblower \& A. Spawforth (eds.), The Oxford classical dictionary, 3rd rev. edn., pp. 245-246, Oxford University Press, Oxford.

Bruce, F.F., 1982, 1 and 2 Thessalonians, Word, Dallas. (Word Biblical Commentary, vol. 45).

Coletti, T., 2009, 'Eco's middle ages and the historical novel', in P. Bondanella (ed.), New essays on Umberto Eco, pp. 71-89, Cambridge University Press, Cambridge.

Crosland, J. (trans.), 1999, The song of Roland, Parentheses Publications, Cambridge. (Old French series)

Daggers, J., 2010, 'Transcendence and the refiguring of God as male, the absolute same', in L. Isherwood \& E. Bellchambers (eds.), Through us, with us, in us: Relational theologies in the twenty-first century, pp. 197-211, SCM, London.

De Botton, A., 2013, Religion for atheists: A non-believer's guide to the uses of religion, Vintage, Random House, New York.

Diamond, J., 1991, The third chimpanzee: The evolution and future of the human animal, HarperCollins, New York.

Eco, U., 1990, The limits of interpretation, Indiana University Press, Bloomington.

Farronato, C., 2003, Eco's chaosmos: From the Middle Ages to postmodernity, University of Toronto Press, Toronto.

Fouz-Hernández, S. (ed.), 2009, Mysterious skin: Male bodies in contemporary cinema, Tauris, London.

Gallagher, C. \& Laqueur, T., 1987, The making of the modern body, sexuality and society in the nineteenth century edited, University of California Press, Berkeley.

Gibson, T.L., 1981, 'The body as theology in pastoral psychology', Journal of Religion and Health 20(4), 288-298. http://dx.doi.org/10.1007/BF01572628

Groppe, C., 2006, 'Body culture', in M. Landfester, H. Cancik \& H. Schneider (eds.), Brill's encyclopaedia of the ancient world, pp. 546-560, Koninklijke Brill, New Pauly.

Irigary, L., 1993, Sexes and genealogies, Columbia University Press, New York.

Isherwood, L., 2010, 'Wanderings in the cosmic garden', in L. Isherwood \& E. Bellchambers (eds.). Through us, with us, in us: Relational theologies in the twenty-first century, pp. 121-132, SCM, London.

Isherwood, L. \& Stuart, E., 1998, Introducing body theology, Sheffield Academic Press, Sheffield.

Jhally, S., 1990, Image based culture: Advertising and popular culture from 'The World and I', viewed 2 July 2014, from http://www.worldandilibrary.com> article 17591

Joyce, R.A., 2005, 'Archaeology of the body', Annual Review of Anthropology, 139158 , viewed 2 July 2014, from http://www.jstor.org/stable/25064880

Kassian, M.A., 1990, Women, creation and the fall, Crossway Books, Westchester.

Kassian, M., 2005, The feminist mystique/mistake, the radical impact of feminism on church and culture, Crossway Publishers, Wheaton.

McDougall, J.A., 2009, 'Feminist theology', in J. Webster, K. Tanner \& I. Torrance (eds.), The Oxford handbook of systematic theology, pp. 670-687, Oxford University Press, Oxford.

McFague, S., 1987, Models of God: Theology for an ecological nuclear age, Fortress, Philadelphia.

Meir, I., Padden, C.A., Aronoff, M. \& Sandler, W., 2007, 'Body as subject', Journal of Linguistics 43(3), 531-563, viewed 2 July 2014, from http://www.jstor.org/ stable/40058012

Mitchell, K., 2006, 'Bodies that matter: Science fiction, technoculture, and the gendered body', Science Fiction Studies 33(1), 109-128, viewed 2 July 2014, from http://www.jstor.org/stable/4241411

Moyo, F.L., 2004, 'Religion, spirituality and being a woman in Africa: Gender construction within the African religio-cultural experiences' - Agenda: Empowering women for gender equity', Religion \& Spirituality 61, 72-78. http:// Empowering women for gender equity', Religion
dx.doi.org/10.1080/10130950.2004.9676045

O'Grady, K., Gilroy, A.L. \& Gray, J.P., 1998, 'Introduction', in K. O'Grady, A.L. Gilroy \& J.P. Gray (eds.), Bodies, lives, voices: Gender in theology, pp. 7-13, Sheffield Academic Press, Sheffield.

Padilla-Tallman, E., 2006, 'Apophatic bodies: Infinity, ethics \& incarnation', and 'Latina Shekinah: Exile and the hope of homemaking', Drew theological school's 6th transdisciplinary Theological Colloquium, student session, abstracts, pp. 1-9, viewed 20 September 2014, from http://depts.drew.edu/tsfac/colloquium/2006/ TTC6gradstudentproposals.pdf

Phiri, I., 2004, 'African women's theologies in the new millennium: Empowering women for gender equity', Religion and Spirituality 18(61), 16-24. http://dx.doi. org/10.1080/10130950.2004.9676034

Phiri, I.A., Haddad, B.G. \& Masenya, M. (eds.), 2003, African women, HIV/AIDS and faith communities, Cluster Publications, Pietermaritzburg.

Piper, J. \& Grudem, W. (eds.), 2006, Recovering biblical manhood and womanhood, Crossway Books, Westchester. 
Potgieter, R., 2013, 'Keith Ward's soft panentheism', In die Skriflig/In Luce Verbi 47(1), Art. \#581, 9 pages. http://dx.doi.org/ 10.4102/ids.v47i1.581

Protevi, J., 2013, 'Body', in L. Lawler \& J. Nale (eds.), The Cambridge Foucault lexicon, pp. 51-57, Cambridge University Press, Cambridge.

Ringleben, J., 2007, 'Body and corporeality', in H.D. Betz, D.S. Browning, B. Janowski, \& E. Jüngel (eds.), Religion past \& present, encyclopedia of theology and religion, vol. 2: Bia-Chr, pp. 145-146, Brill, Leiden.

Rivera, M.R., 2007, The touch of transcendence: A postcolonial theology of God, Westminster John Knox, Louisville.

Rivera, M.R., 2010, 'Unsettling bodies', Journal of Feminist Studies in Religion 26(2), 119-123, viewed 2 July 2014, from http://www.jstor.org/stable/10.2979/ FSR.2010.26.2.119

Rousseau, J.J. n.d., Discourse on inequality, transl. G.D.H. Cole, viewed 27 August 2014, from http://www.nutleyschools.org/userfiles/150/Classes/5377/Discourseonlnequality.pdf

Ruether, R.R., 1983, Sexism and God-talk: Towards a feminist theology, Beacon, Boston.
Ruether, R.R., 2000, 'The God of possibilities: Immanence and transcendence rethought - The brighter side of faith: Concilium', International Journal for Theology 4, 45-54.

Schiebinger, L., 1999, 'Feminist theory and the body', in J. Price \& M. Shildrick (eds.), Theories of gender and race, pp. 21-31, Routledge, New York.

Schildkrout, E., 2004, 'Inscribing the body', Annual Review of Anthropology, 33, 319344. http://dx.doi.org/10.1146/annurev.anthro.33.070203.143947

Spelman, E.V., 1999, 'Woman as body: Ancient and contemporary views', in J. Price \& M. Shildrick (eds.), Feminist theory and the body: A reader, pp. 32-41, Edinburgh University Press, Edinburgh.

Tayyab, B., 1998, 'Islam in a companion to feminist philosophy', in A. Jaggar \& I.M. Young (eds.), A companion to feminist philosophy, pp. 236-244, Blackwell, Oxford.

Wieseltier, L., 2005, 'Jewish bodies, Jewish minds', The Jewish Quarterly Review 95(3), 435-442, viewed 2 July 2014, from http://www.jstor.org/stable/25470085

Wilke, A., 2007, 'Religious studies in article body and soul', in H.D. Betz, D.S. Browning, B. Janowski B Jüngel, \& E. Jüngel (eds.), Religion past \& present, encyclopedia of theology and religion, vol. 2: Bia-Chr, pp. 147-148, Brill, Leiden. 